\title{
TYPES OF GERMAN YOUTH SLANG
}

\section{ВИДИ НІМЕЦЬКОГО МОЛОДІЖНОГО СЛЕНГУ}

\author{
Pozdniakov O.V., \\ orcid.org/0000-0001-7525-7108 \\ Candidate of Philological Sciences, \\ Associate Professor at the Department of Foreign Languages and Country Studies \\ Vasyl Stefanyk Precarpathian National University
}

The article analyzes German youth slang in terms of the possibility of its classification. Youth slang is one of the most dynamic and changeable subsystems of modern German. New lexical and phraseological units are formed and modified with each new generation of young people. Through specific vocabulary, the representatives of the above-mentioned social and age group demonstrate their values and worldview. Some youth slangisms enrich the vocabulary of colloquial and literary styles of German language. As a rule, these words and expressions are recorded in corresponding lexicographical sources. At the same time, youth slang is not an indivisible language subsystem that exists only in a single form. First of all, this is caused by the heterogeneity of the social and age group "youth".

The author divides the studied language subsystem into three types: general, subcultural and intragroup slangs. A number of lexical and semantic criteria were used to compare these means of young people's verbal communication. The first type (common slang) is considered as a set of specific words and expressions that are typical for German-speaking youth without taking into account their cultural, regional, and social heterogeneity. This type of slang is an abstract language subsystem that represents key features of young people's vocabulary. Subcultural slang reflects activities of a particular youth subculture. Its words and expressions include the names of concepts important for fulfilling subcultural roles and demonstrating subcultural affiliation. Because most subcultures, that are popular with German-speaking youth, are of American origin, this type of slang has the largest share of loanwords. Peer group slang is a means of communication for young people of about the same age. The vocabulary of this type of slang is characterized by the highest degree of variability and the most clearly expressed language creativity. The reason for this is the need to express intragroup identity. All these types of youth slang are interconnected with each other and other subsystems of German language affecting their development.

Key words: German language, social and age group, subcultural group, peer group, vocabulary, loanwords.

У статті проаналізовано німецький молодіжний сленг з позицій можливості його класифікації. Молодіжний сленг $€$ однією з найбільш динамічних підсистем сучасної німецької мови. Нові молодіжні лексичні та фразеологічні одиниці утворюються та видозмінюються разом з появою кожного нового покоління молодих людей. Через особливий словниковий запас молоді комуніканти демонструють свої цінності та світосприйняття. Окремі молодіжні сленгізми стають елементами вокабуляру розмовного та літературного стилів німецької мови, а також фріксуються у відповідних лексикографічних джерелах. Водночас молодіжний сленг не $є$ неподільною мовною субсистемою, котра існує лише в єдиній формі. Насамперед це зумовлене неоднорідністю соціально-вікової групи «молодь».

Автор поділяє досліджувану мовну підсистему на три види: загальний, субкультурний та внутрішньогруповий сленги. Для зіставного опису зазначених засобів вербальної комунікації молодих людей застосовано низку лексичних і семантичних критеріїв. Перший вид сленгу (загальний) розглядається як сукупність специфрічних слів і виразів, які характерні для спілкування німецькомовної молоді без урахування їх культурної, регіональної, соціальної неоднорідності. Цей вид сленгу є абстрактною мовною підсистемою, який репрезентує ключові особливості вокабуляру молодих людей. Субкультурний сленг відображає діяльність тієї чи іншої молодіжної субкультури. Його слова та вирази включають найменування понять, важливих для виконання субкультурних ролей та демонстрації субкультурної приналежності. У зв'язку з американським походженням більшості популярних на німецькомовній території молодіжних субкультур цей тип сленгу відзначається найбільшою часткою запозичень. Внутрішньогруповий вид сленгу є засобом спілкування молодих людей приблизно однакового віку. Для словникового складу такого типу сленгу притаманні найбільший ступінь мінливості та найяскравіше виражена мовна креативність. Однієї з причин цього є потреба вираження внутрішньогрупової ідентичності. Всі перелічені види молодіжного сленгу перебувають у взаємозв'язку один з одним та з іншими підсистемами німецької мови, впливаючи на їх розвиток.

Ключові слова: німецька мова, соціально-вікова група, субкультурна група, група однолітків, словниковий склад, запозичення.

Formulation of the problem. The need for identifying and distinguishing the main types of youth slang is caused by its growing influence on the development of standard German language. Besides, the researched linguistic phenomenon is one the most rapidly changing and evolving language subsystems. Young people's vocabulary reflects global processes in society.
Youth slang is a component of the German language and occupies an important place in its overall system. Evidence of this is the intensification of using slang words and expressions at the level of nation-wide communication. Another example of importance of the given vocabulary is its proliferation through mass-media that are regarded as a mirror of today's language evolution. At the same time, 
in the process of long-term development, youth slang has acquired the features of a separate system with specific characteristics at different language levels, primarily at the lexical-semantic level. The variability of the combination of these features in particular communicative situations shows the variability of youth slang itself providing the opportunity for its intra-system differentiation and classification.

Analysis of recent research and publications has shown that many philologists of German language are pointing to the heterogeneity of youth slang, which is determined by the heterogeneity of the social and age group "youth".

Different types of youth slang are a reflection of the heterogeneity of the language community, the diversity of social, cultural, historical and political conditions for the existence and development of society and the increasing requirements and needs of using language for communication needs in general $[10$, p. 55].

According to P. Shlobinski, there can be no universal young people's vocabulary, because young people themselves are not a homogeneous social and age group [15, p. 27]. At the level of microgroups, there are as many youth slang versions as there are particular groups of their users. Furthermore, it has been shown that already at the level of primary groups of young people (such as class of pupils or students) there are various competing language forms [6, p. 75]. That may be regarded as evidence of the purely individual nature of the realization of the researched linguistic phenomenon, which is determined by a communicative situation.

At the same time, in modern German studies, the term "German youth slang" is often mentioned to denote the specific vocabulary, which is used by the total number of the representatives of Germanspeaking young people regardless their social, educational, regional or cultural affiliation [3, p. 462].

Scientific novelty of the article is that it proposes a number of new lexical and semantic criteria for the classification of German youth slang.

The purpose of the article is to single out the types of German youth slang and compare them based on their distinguishing features. In the given research, our task is to identify the lexical and semantic characteristics of the types of young people's vocabulary and determine their place in the researched language subsystem. That is why as a subject of our study the intra-system lexical and semantic features of German youth slang have been chosen.

Results and discussions. Taking into account the internal heterogeneity of youth, the representatives of this part of the society can be divided into three group types: peer groups, subcultural groups and the common social and age group of young people [14, p. 2].

Peer groups are groups of young people of about the same age. They play the most important role during the period of transition from childhood, which is usually strong regulated by family traditions, to individual lifestyle and adulthood. The awareness of being member of a group arises on the basis of common interests in a particular sport, musical style or fashion and causes dissociation from non-members of the group [11, p. 24]. The need for intra-group identity is often expressed in language by means of using specific words and expressions.

One of the main characteristics of youth subcultures is the unity of their representatives in relation to cultural values and lifestyle. As a rule, these common features are formed as a result of the influence of the mass-media [6, p. 90]. Most subcultures preferred by German-speaking young people are of American origin. Their popularizing mainly through social networks contributes to the growing importance of youth and youth subcultures at the supraregional level. An important factor is the ability of young people to adapt to the latest technologies. Social media create a specific sort of community with the possibility of virtual, indirect contacts, which facilitates an increase in the number of participants in subculturally determined communication processes.

The common social and age group of young people integrates the representatives of all peer groups and subcultures to form a global community of German-speaking youth [5, p. 20].

Thus, according to this classification of youth, three types of youth slang can be singled out:

- peer group slang - vocabulary typical for members of a specific group of young people;

- subcultural slang - vocabulary of young people that belong to a particular subculture;

- common slang - vocabulary of the representatives of the social and age group "youth" regardless their educational, regional or cultural affiliation.

To describe each of these three types of youth slang, we use a set of lexical and semantic criteria, that reveal distinguishing features of the researched language subsystem.

German youth slang is a heterogeneous language subsystem. Despite of its heterogeneity, the given linguistic phenomenon has some common basic principles and structures [11, p. 75]. Common youth slang is an abstract linguistic phenomenon formed as a result of compiling particular forms of young people's communication. It shows the linguistic characteristics of the representatives of the social 
and age group "youth" in general (in particular, as an alternative to the colloquial and literary types of German language).

The universality of common slang in terms of its vocabulary goes hand in hand with dynamic changes in its composition. New words and expressions arise at the level of communication of particular peer groups and become soon part of everyday life and use throughout German-speaking milieu. After several years, these lexical and phraseological units lose their popularity, but remain recorded in dictionaries [2, p. 95]. Changes in slang vocabulary are determined by the changes of generations of its active creators and users.

According to K.V. Kulakova, the analysis of new slangisms can help to single out topics and events, which have received the most attention by young people during a particular year [1, p. 25].

Since 2008, the "Youth word of the year" (German: "Jugendwort des Jahres") is selected annually [9]. In 2008 it was Gammelfleischparty - Party für Menschen über 30 Jahren; in 2015 - Smombie (von "Smartphone" und "Zombie") - Menschen, die durch den ständigen Blick auf ihr Smartphone so stark abgelenkt seien, dass sie ihre Umgebung kaum noch wahrnehmen würden; in 2020 the most popular word was lost - ahnungslost, verloren, verirrt.

The subcultural slang vocabulary is relatively less changeable due to the fact that its main function is to denote the concepts of a particular subcultural style. Each of the subcultural styles is characterized by its own history, values, activities, hierarchy of interrelations, symbols determining affiliation to this style. Sustainability of subcultural concepts determines sustainability of words and expressions used to name them (AFK - Ausdruck von Computerspielern / Internetnutzern (Chat) für deren Abwesenheit; Favicon - ein kleines Mini-Logo, das in der Adresszeile des Browsers ikonisiert für eine Webseite steht).

Compared to common and subculcural types of slang, vocabulary of peer groups is the most dynamic language subsystem in terms of forming new lexical and phraseological units. On the other hand, the potential of young people's language creativity is most fully realized exactly at the level of intragroup communication (Rentnerporsche-Gehhilfe, meistinFormeinesRollators oder Rollstuhls; Bananenbieger - Person, die eine einfache Aufgabe nicht lösen kann oder überflüssig viel Aufwand dazu betreibt).

Most youth vocabulary is restricted by certain thematic groups that are of particular interest to young people and are an important part of their everyday life
[8, p. 212] (verhaften - Bier trinken; Zungentangoheftiger Zungenkuss).

At the same time, subcultural slang vocabulary includes more words and expressions professional semantics reflecting activities of the given subculture, which can play different roles in the lives of its members (Violent Dancing - eine besonder Art des "Slamdances" auf Hardcore-Konzerten; uprocken Tanzen mit komletten Körpereinsatz, so dass man alles um sich herum vergisst). Thus, vocabulary of three types of youth slang has different potential to achieve a higher level of use, namely colloquial and literary styles of German language.

All three types of youth slang interact with each other, as well as with the vocabulary of other subsystems of German language. From this point of view, the vocabulary of common youth slang is much more open system, because it interacts with subcultural and peer group slangs, on the one hand, and colloquial and literary styles of German, on the other hand. Its words and expressions refer to common concepts that form the environment for young people's activities, and are understood at the level of nation-wide communication (natschig - wenn man sich nichts Vernünftiges anstellen mag und sich mit der Situation trotzdem nicht zufrieden gibt; Schokoholiker - Person, die süchtig nach Schokolade ist).

Determining the meaning of peer group and subcultural vocabulary requires additional knowledge, which is the result of understanding the features of a particular peer group or subcultural style (Frag Töten eines Gegners in EGO Shootern; Kuduro Tanzstil, der sich aus dem Breakdance entwickelt hat).

Words and expressions of common and subcultural types of slang are often recorded in specific lexicographic sources - dictionaries of common slang [12;13] (hazen, schmoggen, barzen - eine Zigarette rauchen; Spacko, Spast-dumme Person) and subcultural slang [7] (rushen - eine besonders in Strategiespielen vorkommende Taktik; Serverfarm eine Gruppe von gleichartigen, vernetzten Servern, die zu einem logischen System verbunden sind und optimiert die internen Prozesse durch Verteilung der Auslastung).

Lexicographic recording of peer group vocabulary is less practiced because of the small number of members of a particular peer group and the instability of their vocabulary.

As previously mentioned, common youth slang is an abstract linguistic phenomenon, which characterizes the peculiarities of communication of the researched social and age group. In contrast to this type, peer group and subcultural slangs are 
real patterns of young people's communication (Schleppschrott - schlechter Laptop; Chiefcheckerjemand, der alles versteht, kann, schafft, bekommt). Distinction in their vocabulary depends on the plurality of peer groups, as well as the diversity of subcultural styles. New words and expression arise to name new concepts [4, p. 13].

Lexical and semantic feature of modern German youth slang is rapidly increasing use of loanwords, first of all Anglo-Americanisms (tight (Hip-HopAusdruck) - cool, talentiert; Keylogger - Hard-oder Software, die dazu verwendet wird, die Eingaben des Benutzers an einem Computer mitzuprotokollieren und dadurch zu überwachen oder zu rekonstruieren).

Subcultural slang is characterized by a larger proportion of loanwords. On the one hand, this can be explained by the global role of English language in international communication. On the other hand, most subcultural styles are of American origin (Moshpit Teil des Publikums, der bei Musikkonzerten direkt vor der Bühne steht und tanzt; Blogroll - Liste der Blog-Empfehlungen, die ein Blogger für seine Leser zwecks besserer Vernetzung abgibt).

Vocabulary of common and peer group slangs is characterized by a larger share of national, and in particular regional words and expressions. The historical development of German language plays an important role in this process. Many slangisms derive from territorial dialects (Zichte - Berlinerisch für "Zigarette"; Moler - sächsisch für "Bonbons").
Conclusions. German youth slang is a heterogeneous linguistic phenomenon, which can be divided into several types. As a means of communication, it is used as peer group and subcultural slangs.

On the other hand, the common features of lifestyle and values of German-speaking young people make possible the existence of supraregional and supragroup slang, which is the result of the compilation of particular slangs, but not their sum.

Common youth slang is typical for nation-wide communication of young people. It is characterized by common features of its use by native speakers at all language levels, primarily at the lexical-semantic level. Words and expressions, which belong to the common German youth vocabulary, are recorded in specific lexicographic sources. This type of slang forms the core for other types of slangs.

All types of German youth vocabulary reflect the evolutionary trends of the society in general, demonstrating the communicative and creative potential of the representatives of the given social and age group.

Slang vocabulary enriches the vocabulary of colloquial and literary styles of German language and can be further recorded in standard and specific lexicographic sources.

We see prospects for further research in a detailed study of each of the above-mentioned types of youth slang in order to find out the ways of their interaction and clarify their role in the development of the whole system of German language.

\section{REFERENCES:}

1. Кулакова К.В. Молодежный сленг как отражение современной действительности. Вестник Балтийского федерального университета им. И. Канта. Филология, педагогика, психология. Калининград, 2019. № 4. C. 23-30.

2. Левицька Л.Я., Микитка І.С. Німецький молодіжний сленг та його лексико-семантичні особливості. Вісник Харківського національного університету імені В.Н. Каразіна. Філологія. Харків, 2013. № 1052. Вип. 74. C. 94-99.

3. Androutsopoulos J.K. Deutsche Jugendsprache. Untersuchungen zu ihren Strukturen und Funktionen. Frankfurt am Main, New York: Peter Lang, 1998. 684 S.

4. Androutsopouols J.K. Mode, Medien und Musik : Jugendliche als Sprachexperten. Der Deutschunterricht. 1997. № 6. S. 10-20.

5. Bruder-Bezzel A., Bruder-Bezzel K.-J. Jugend. Psychologie einer Kultur. München, 1984. S.20.

6. Chun M. Jugendsprache in den Medien. Eine Jugendsprachliche Analyse von Jugendromanen, Hip-HopTexten und Kinofilmen [1. Aufl.]. Saarbrücken : VDM Verlag Dr. Müller, 2007. 352 S.

7. Duden - Das neu Wörterbuch der Szenesprachen. Duden, 2009. 208 S.

8. Henne H. Jugend und ihre Sprache : Darstellung, Materialien, Kritik. Berlin; New York : de Gruyter, 1986. $385 \mathrm{~S}$.

9. Jugendwort der Jahres (Deutschland). URL: https://de.wikipedia.org/wiki/Jugendwort_des_Jahres_ (Deutschland) (Last accessed: 04.03.2021).

10. Kramorenko G.I. Zum Problem der Heterogenität der Jugendsprache und inrer lexikalisch-semantischen Charakteristik. Das Wort. Germanistisches Jahrbuch. Moskau : DAAD, 1995. S. 47-57.

11.Nowottnick M. Jugend, Sprache und Medien. Untersuchungen zu Rundfunksendungen für Jugendliche. Berlin, NewYork : de Gruyter, 1989. 416 S.

12. PONS 15 Jahre Wörterbuch der Jugendsprache - Sammelband : Das Original - unzensiert [1. Aufl.]. Stuttgart : PONS, 2016. 288 S. 
13. PONS Wörterbuch der Jugendsprache 2017. Stuttgart: PONS, 2016. 144 S.

14. Reinke M. Jugend, Sprache und Medien. Am Beispiel von Rundfunksendungen für Jugendliche. Hannover, 2000. 19 S.

15. Schlobinski P., Kohl G., Ludewigt J. Jugendsprache. Fiktion und Wirklichkeit. Opladen : Westdeutscher Verlag, 1993. $223 \mathrm{~S}$.

УДК 81'42:821.112-32

DOI https://doi.org/10.32782/tps2663-4880/2021.15.15

\title{
ТЕКСТИ МАЛИХ ХУДОЖНІХ ФОРМ В ІНТЕРПРЕТАЦІЙНОМУ ВИМІРІ: ЛІНГВОСТИЛІСТИЧНИЙ АСПЕКТ
}

\section{SHORT STORY TEXTS IN THE INTERPRETATIVE DIMENSION: LINGUO-STYLISTIC ASPECT}

\author{
Яремчук I.M., \\ orcid.org/0000-0002-3024-5143 \\ кандидат філологічних наук, \\ старший викладач кафедри німецької мови \\ Кам'янеиь-Подільського начіонального університету імені Івана Огієнка
}

\begin{abstract}
У статті розглянуто тексти малих художніх форм в інтерпретаційному вимірі з урахуванням лінгвостилістичних характеристик. Особлива увага звертається на поняття «лінгвостилістична інтерпретація тексту». Встановлено, що необхідність використання методу лінгвостилістичної інтерпретації текстів малих художніх форм дає можливість визначити типологізацію, прагматичні функції, стильові риси художнього тексту.

У результаті системного вивчення німецькомовної притчі як жанру й типу тексту та лінгвостилістичної інтерпретації текстів була розроблена дефініція притчі, у якій враховані соціальні, комунікативні, художньо-естетичні цілі та їх мовні засоби досягнення. Встановлено, що у результаті лінгвостилістичної інтерпретації тексту притчі здійснюється реалізація низки прагматичних функцій, а саме дидактичної, комунікативної, етико-філософсьької, соціально-критичної, функції впливу, інтерпретаційно-прагматичної, евристичної, ілюстративно-риторичної, виховної, сатиричної, драматичної, інформаційної, функції іносказання. Цей вибір обумовлений авторськими інтенціями, а також жанром, у якому побудовано текст. Шляхом інтерпретації текстів притч та використанню аналізу за стильовими рисами виокремлено такі стильові риси, як стислість/відносна стислість/розгорнутість, сюжетність, двоплановість, символічність, діалогічність/монологічність, статичність/динамічність, дидактичність, автологічність/експресивність.

Зазначено, що німецькомовна байка $є$ унікальною як особливий жанр літератури та різновид тексту, а також належить до текстів малих художніх форм. Крім того, наголошено на плідності результатів роботи за рекомендаційним планом лінгвостилістичної інтерпретації тексту байки.
\end{abstract}

Зроблено висновок, що використання методу лінгвостилістичної інтерпретації слугує для детального опису лінгвістичної природи німецькомовної притчі та усіх текстів жанрів малих форм.

Ключові слова: байка, лінгвостилістична інтерпретація, план аналізу, притча, текст, функція.

The article considers the short story texts in the interpretive dimension, taking into account their linguistic and stylistic characteristics. Particular attention is paid to the concept of "linguistic and stylistic interpretation of the text". It is established that the need to use the method of linguistic-stylistic interpretation of short story texts makes it possible to determine their typology, pragmatic functions, and stylistic features.

As a result of systematic study of the German-language parable as a genre and type of text and linguistic-stylistic interpretation of texts, a definition of the parable was developed, which takes into account social, communicative, artistic, and aesthetic goals and their linguistic means of achievement. It is established that as a result of linguistic and stylistic interpretation of the parable the realization of a number of pragmatic functions is carried out: didactic, communicative, ethical-philosophical, social-critical, influence functional, interpretive-pragmatic, heuristic, illustrative-rhetorical, educational, satirical, dramatic, and informative. This choice is due to the author's intentions, as well as the genre in which the text is built. By interpreting the texts of parables and using the analysis of stylistic features, the following stylistic features are identified: brevity/relative brevity/development, plot, dichotomy, symbolism, dialogic/monologue, static/dynamic, didactic, and autological/expressive.

It is noted that the German-language fable is unique as a special genre of literature and a variety of text; it also belongs to the short story texts. In addition, the fruitfulness of the results of the work on the recommended plan of linguistic and stylistic interpretation of the text of the fable is emphasized.

It is concluded that the use of the method of linguistic-stylistic interpretation serves to describe in detail the linguistic nature of the German-language parable and other texts of short story genre.

Key words: fable, linguistic-stylistic interpretation, analysis plan, parable, text, function. 